\title{
Purification and partial characterisation of a lectin from the red marine alga Vidalia obtusiloba C. Agardh
}

\author{
FÁBIO R. MELO ${ }^{1}$, NORMA M.B. BENEVIDES ${ }^{1,2}$, MARIA G. PEREIRA ${ }^{1}$, \\ MÁRJORY L. HOLANDA ${ }^{1}$, FRANCISCA N.P. MENDES ${ }^{1}$, STÉLIO R.M. OLIVEIRA ${ }^{1}$, \\ ANA L.P. FREITAS and LUANA M.C.M. SILVA ${ }^{1}$
}

(received: December 26, 2002; accepted: January 8, 2004)

\begin{abstract}
Purification and partial characterisation of a lectin from the red marine alga Vidalia obtusiloba C. Agardh). The lectin of the red marine alga Vidalia obtusiloba was purified by a combination of ammonium sulphate precipitation, ionexchange chromatography on DEAE-cellulose and affinity chromatography on cross-linked guar gum. The lectin preferentially agglutinated native and bromelain-treated human group $\mathrm{O}$ erythrocytes. The haemagglutinating activity revealed that the lectin was dependent on divalent cations $\left(\mathrm{Ca}^{++}\right.$or $\left.\mathrm{Mn}^{++}\right)$and was shown to be inhibited by $\mathrm{N}$-acetyl-galactosamine, $\mathrm{D}$-galactosamine, $\alpha$-lactose and D-galactose and by the glycoprotein porcine stomach mucin. The molecular mass of the lectin, estimated by gel filtration, was $78.9 \mathrm{kDa}$ while by SDS-PAGE, in the presence of $\beta$-mercaptoethanol, the lectin exhibited two different protein subunits with $\mathrm{M}_{\mathrm{r}}$ of 59.6 and $15.2 \mathrm{kDa}$, suggesting that the lectin is a dimeric protein. Isoelectric focusing revealed the presence of a simple acidic protein with an isoelectric point between 4 and 5 . The purified lectin showed a carbohydrate content of $43.2 \%$ and a predominance of the amino acids Asp/Asn, Glu/Gln and Leu. The energy of activation $\left(\Delta \mathrm{G}^{\prime}\right)$ for the denaturation of the lectin was estimated to be $25.4 \mathrm{kcal} . \mathrm{mol}^{-1}$ at $90^{\circ} \mathrm{C}$. Immunochemical assays using a rabbit antiserum raised against the purified lectin of $V$. obtusiloba showed that it was possible to detect the presence of the lectin at different steps of the purification process. Western blotting of SDS-PAGE gels showed immunostaining of only the larger of the lectin subunits.
\end{abstract}

Key words - hemagglutinin, lectin, protein, red marine alga

RESUMO - (Purificação e caracterização parcial de uma lectina da alga marinha vermelha Vidalia obtusiloba C. Agardh). A lectina da alga marinha vermelha Vidalia obtusiloba foi purificada através da combinação de precipitação com sulfato de amônio, cromatografia de troca iônica em DEAE-celulose e cromatografia de afinidade em goma de guar reticulada. A lectina preferencialmente aglutinou eritrócitos do grupo humano $\mathrm{O}$, nativos e tratados com bromelaina. A atividade hemaglutinante revelou que a lectina era dependente de cátions divalentes $\left(\mathrm{Ca}^{++} \mathrm{ou} \mathrm{Mn}^{++}\right)$e inibida por $\mathrm{N}$-acetil-galactosamina, D-galactosamina, $\alpha$-lactose and D-galactose e pela glicoproteína mucina de estômago de porco. A massa molecular da lectina, estimada por filtração em gel, foi de 78,9 kDa, enquanto por SDS-PAGE, em presença de $\beta$-mercaptoetanol, a lectina exibiu duas subunidades protéicas diferentes com $\mathrm{Mr}$ de 59,6 e 15,2 kDa, sugerindo que a lectina é uma proteína dimérica. Focalização isoelétrica revelou a presença de uma proteína ácida simples, com um ponto isoelétrico entre 4 e 5 . A lectina purificada exibiu um conteúdo de carboidrato de 43,2\% e uma predominância dos aminoácidos Asp/Asn, Glu/Gln e Leu. A energia de ativação ( $\left.\Delta G^{\prime}\right)$ para a desnaturação da lectina foi calculada como sendo $25,4 \mathrm{kcalm} \cdot \mathrm{mol}^{-1}$ a $90{ }^{\circ} \mathrm{C}$. Ensaios imunoquímicos usando um anti-soro de coelho produzido contra a lectina purificada de $V$. obtusiloba mostraram que foi possível detectar a presença da lectina em diferentes etapas do processo de purificação. Western blotting de géis de SDS-PAGE mostraram imunocoramento apenas da maior das subunidades da lectina.

Palavras-chave - alga marinha vermelha, hemaglutinina, lectina, proteína

\section{Introduction}

Lectins (from Latin, legere, to select or choose) are proteins that binding mono- and oligosaccharides specifically and reversibly but are devoid of catalytic activity (i.e. are not enzymes) and, in contrast to

\footnotetext{
1. Universidade Federal do Ceará, Departamento de Bioquímica e Biologia Molecular, Caixa Postal 6020, 60451-970 Fortaleza, CE, Brazil.

2. Corresponding author: nmbb@ufc.br
}

antibodies, are not products of an immune response (Sharon \& Lis 1989). They are widely distributed in nature and can be found in almost all living organisms including plants, algae, fungi, animals (vertebrates and invertebrates), micro-organisms and viruses. Lectins have been isolated and characterised from various biological sources, mainly land plants. Though in many instances their exact biological roles remain elusive, lectins from animals and land plants have been extensively exploited as biochemical tools in biotechnology and biomedical research (Van Driessche 
et al. 1996, Gabius \& Gabius 1997, Lis \& Sharon 1998). However, there is only a limited amount of information on purified and characterised algal lectins, compared to those for lectins of higher plants and invertebrates (Rogers \& Hori 1993). Algal lectins differ from higher plant lectins in a variety of properties. In general, algal lectins have lower molecular masses then most higher plant lectins and have no affinity for simple sugars but are more specific for complex oligosaccharides, often glycoproteins. Furthermore, most of marine algal lectins do not require divalent cations for their biological activity (Rogers \& Hori 1993). They occur mainly in monomeric forms and have a high proportion of acidic amino acids, with isoeletric points from 4 to 6 (Shiomi et al. 1981, Hori et al. 1990). Most algal lectins have been isolated from red algae, such as Bryothamnion seaforthii (Turner) Kützing and B. triquetrum (Gmelim) Howe (Ainouz et al. 1995), Solieria filiformis (Kützing) Gabrielson (Benevides et al. 1996), Enantiocladia duperreyi (C. Agardh) Falkenberg (Benevides et al. 1998) and Pterocladiella capillacea Santel \& Hommers (Oliveira et al. 2002). The lectins isolated from red marine algae Bryothamnion triquetrum (Gmelim) Howe and Hypnea japonica Tanaka were the first lectins to have their primary structure elucidated by Calvete et al. (2000) and Hori et al. (2000), respectively. In spite of the progress made in the biochemical characterisation of marine algal lectins, additional information is needed for a more comprehensive understanding of their properties, structures and possible biological functions. The present work describes the purification and partial characterisation of a lectin from the red marine alga Vidalia obtusiloba C. Agardh.

\section{Material and methods}

The red alga Vidalia obtusiloba C. Agardh was collected from Pacheco beach (Fortaleza, Ceará, Brazil). After collection, the material was cleaned of epiphytes, washed with distilled water and stored at $-20{ }^{\circ} \mathrm{C}$ until use.

Human blood group A, B and O erythrocytes were collected from healthy donors at the Hematology Center, Federal University of Ceará (UFC). Rabbit, ox, goat and chicken erythrocytes were obtained by venous puncture of healthy animals.

The lectin of the red marine alga Vidalia obtusiloba was purified by extraction of soluble proteins in $20 \mathrm{mM}$ Tris-HCl buffer, $\mathrm{pH} 7.5$, containing $0.005 \mathrm{M} \mathrm{CaCl}_{2}$ (TB) following the procedures as described by Oliveira et al. (2002). The crude extract was previously submitted to the treatment with $60 \%$ saturated ammonium sulphate and the protein fraction $0 \%-60 \%$ obtained was subjected to ion exchange chromatography on a column of DEAE-cellulose. The fraction containing the hemagglutinating activity was pooled and further purified by affinity chromatography on a column of cross-linked guar gum.

Protein and carbohydrate contents were determined by the methods of Bradford (1976) and Dubois et al. (1956) using bovine serum albumin and glucose as the calibration standard, respectively. The absorbance at $280 \mathrm{~nm}$ was used to estimate protein content in column eluates.

The blood specificity from the Vidalia obtusiloba lectin was determined by use of erythrocytes from different animals (rabbit, chicken, ox, goat) and humans from the ABO system, native and treated with the enzymes trypsin, bromelain, papain and subtilisin, according to Oliveira et al. (2002).

Hemagglutinating activity assay and hemagglutinating activity inhibition assay with carbohydrate and glycoproteins were performed as described previously by Benevides et al. (1998) using bromelain-treated human group O erythrocytes.

The purified lectin was tested for the effect of EDTA and heat on the hemagglutinating activity following standard methodology as described previously by Benevides et al (1998).

The native molecular mass of the Vidalia obtusiloba lectin was determined by gel filtration chromatography on a Sephadex G-100 column equilibrated and eluted with TB. Bovine serum albumin $(66 \mathrm{kDa})$, carbonic anhydrase $(29 \mathrm{kDa})$ and cytochrome $\mathrm{C}(12.4 \mathrm{kDa})$ were used as standard proteins. The void volume (Vo) was estimated with Blue Dextran (Sigma).

The electrofocusing procedure on a $4 \%(\mathrm{w} / \mathrm{v})$ acrylamide gel was carried out using an ampholyte $\mathrm{pH}$ 3.5-10.0 mixture at a concentration of $1.5 \%$ and $10 \%$ sucrose. Pre-running was performed at a constant current of $1 \mathrm{~mA}$ for $30 \mathrm{~min}$ to form the pH gradient. Strips of filter paper impregnated with $1 \%$ sulphuric acid and $1 \%$ ethanolamine were placed in the anode and cathode compartments, respectively. Samples $(20 \mu \mathrm{L})$ on Whatman $\mathrm{N}^{\circ} 1$ filter paper were applied and the gels were run for $60 \mathrm{~min}$ at a current of $500 \mathrm{~V} / 15 \mathrm{~mA}$ followed by $700 \mathrm{~V} / 15 \mathrm{~mA}$ for $60 \mathrm{~min}$. The gels were fixed with $20 \%$ trichloroacetic acid (TCA) for $30 \mathrm{~min}$, and silver stained as described by Blum et al. (1987). Isoelectric points were estimated using amidoglycosidase (pI 3.55), trypsin inhibitor (pI 4.55), $\beta$-lactoglobulin A (pI 5.13), bovine carbonic anhydrase B (pI 5.85), human carbonic anhydrase B (pI 6.57) and myoglobin (pIs 6.76 and 7.16) as standards.

The amino acid analysis of the purified lectin was carried out after hydrolysis of the lectin sample with $6 \mathrm{M} \mathrm{HCl}$ for $24 \mathrm{~h}$ at $110^{\circ} \mathrm{C}$ in glass tubes sealed under $\mathrm{N}_{2}$. After hydrolysis, $\mathrm{HCl}$ was removed by evaporation and the residue was analysed in a Biocrom-20, Pharmacia-LKB. Tryptophan content was measured following the method of Goodwing \& Morton (1946).

Descontinuous electrophoresis was carried out in a vertical system following the Laemmli procedure as described by Hames \& Rickwood (1983). A $12.5 \%$ polyacrylamide slab 
in $0.025 \mathrm{M}$ tris- $\mathrm{HCl}, 0.2 \mathrm{M}$ glycine, $\mathrm{pH} 8.9$, with $0.1 \%$ sodium dodecyl sulfate was used. Samples and standard were prepared in tris- $\mathrm{HCl}$ buffer, $\mathrm{pH}$ 6.8, containing SDS and $\beta$-mercaptoethanol. A low-molecular mass (14.4 to $94 \mathrm{kDa})$ protein marker kit (Sigma) was used to determine approximate protein size. Samples and standards were treated with SDS and $\beta$-mercaptoethanol. Proteins were visualised by the standard silver staining method described by Blum et al. (1987).

\section{Results}

Vidalia obtusiloba lectin was purified by ionexchange chromatography using DEAE-cellulose (figure 1), followed by guar gum affinity chromatography (figure 2). Table 1 shows the results of the steps used in the purification of the lectin. Treatment of the crude extract of V. obtusiloba with $60 \%$ saturated ammonium sulphate led to a 4.5 -fold purification of lectin activity, with a specific activity of 117 HU.mg protein ${ }^{-1}$. When, the ammonium sulphate fraction $0 \%-60 \%$ was subjected to ion exchange chromatography on a DEAE-cellulose column, all the haemagglutinating activity present bound to the gel and was subsequently eluted (PII-DEAE) with the addition of $0.5 \mathrm{M} \mathrm{NaCl}$ to the buffer. This step led to a 16.5 -fold purification with an increase in specific activity to 427 HU.mg protein ${ }^{-1}$. These procedures were effective to eliminate pigments and small molecular weight compounds and to concentrate the preparations. When the PII-DEAE fraction was submitted to affinity

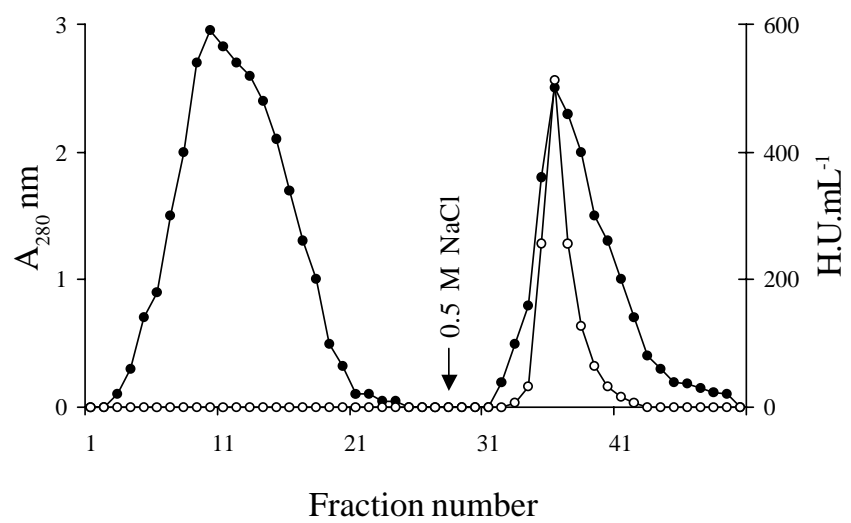

Figure 1. DEAE-cellulose ion-exchange chromatography of the ammonium sulphate fraction (F0/60) of Vidalia obtusiloba extract. The column was equilibrated with TB and washed to remove unbound proteins. The adsorbed protein was eluted with $0.025 \mathrm{M}$ Tris-HCl buffer, $\mathrm{pH} 7.5$, containing $0.005 \mathrm{M}$ $\mathrm{CaCl}_{2}$ and $0.5 \mathrm{M} \mathrm{NaCl}$. $(\bullet \bullet)$ absorbance at $280 \mathrm{~nm} \mathrm{( \circ -)}$ haemagglutinating activity.

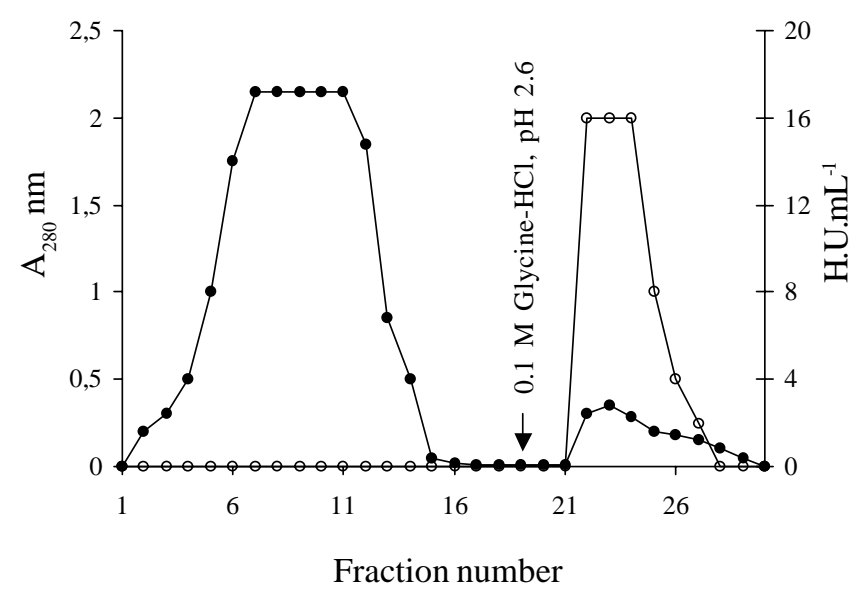

Figure 2. Affinity chromatography of Vidalia obtusiloba lectin on guar gum column. The column was equilibrated with TB to remove unbound proteins. The adsorbed lectin was eluted with $0.1 \mathrm{M}$ glycine-HCl buffer, $\mathrm{pH} 2.6$, containing $0.15 \mathrm{M} \mathrm{NaCl}$ $(\bullet-\bullet)$ absorbance at $280 \mathrm{~nm},\left(\mathrm{O}^{-} \mathrm{O}\right)$ haemagglutinating activity.

chromatography in a column packed with cross-linked guar gum, all the haemagglutinating activity was bound to the gel and subsequently eluted with $0.1 \mathrm{M}$ glycine$\mathrm{HCl}, \mathrm{pH} 2.6$, containing $0.15 \mathrm{M} \mathrm{NaCl}$. This step led to a 20.6-fold purification with an increase in specific activity of the lectin present in the crude extract to 533 HU.mg protein ${ }^{-1}$.

The native purified lectin appeared as a single band on PAGE (not shown) and two bands on SDS- PAGE in the presence of $\beta$-mercaptoethanol corresponding to molecular weights of 59.6 and $15.2 \mathrm{kDa}$ (figure 3 ). The homogeneity of the lectin was also evident with the yielding of a single symmetrical peak by size-exclusion chromatography on Sephadex G-100 in TB (not shown), with an apparent molecular weight of $78.9 \mathrm{kDa}$. The isoelectric focusing of purified lectin revealed the presence of a simple acidic protein band with a $\mathrm{pI}$ between 4 and 5 .

The amino acid composition of the purified lectin is presented in table 2. The lectin is rich in glutamic and aspartic acids and in the hydrophobic amino acid leucine, but has a low content of cystine and methionine. Carbohydrate analysis by the phenol-sulphuric acid method showed that the lectin contains $43.2 \%$ sugar.

Among the erythrocytes analysed (human blood group $\mathrm{A}, \mathrm{B}$ and $\mathrm{O}$ and the animals ox, goat, chicken, and rabbit), the lectin obtained from $V$. obtusiloba exhibited a preference for human bromelain-treated blood group O erythrocytes $\left(2^{8}\right)$ followed by $\mathrm{A}\left(2^{5}\right)$ and rabbit $\left(2^{4}\right)$ erythrocytes. The result of the studies of the 
Table 1. Purification of the lectin from Vidalia obtusiloba. $\mathrm{HU}=$ haemagglutinating units. MAC = Minimum Agglutination Capacity (minimum amount of protein that is still able to agglutinate enzyme-treated human group $\mathrm{O}$ erythrocytes).

\begin{tabular}{|c|c|c|c|c|c|c|}
\hline \multirow[b]{2}{*}{ Fraction } & \multirow{2}{*}{$\begin{array}{c}\text { Protein } \\
\text { total }(\mathrm{mg})\end{array}$} & \multicolumn{2}{|c|}{ Specific Activity } & \multirow{2}{*}{$\begin{array}{r}\text { Yield } \\
(\%)\end{array}$} & \multirow{2}{*}{$\begin{array}{l}\text { Purification } \\
\text { (fold) }\end{array}$} & \multirow{2}{*}{$\begin{array}{l}\text { MAC } \\
\text { mg.mL }{ }^{-1}\end{array}$} \\
\hline & & HU mg P $\mathrm{P}^{-1}$ & Total & & & \\
\hline Aqueous extract & 434.00 & 25.8 & 11,200 & 100.00 & 1.0 & 0.039 \\
\hline Fraction 0\%-60\% & 63.00 & 117.0 & 7,420 & 14.60 & 4.5 & 0.008 \\
\hline PII - DEAE & 1.80 & 427.0 & 768 & 0.40 & 16.5 & 0.004 \\
\hline Guar gum & 0.66 & 533.0 & 352 & 0.15 & 20.6 & 0.002 \\
\hline
\end{tabular}

hemagglutination inhibition with the purified lectin using simple sugars and glycoproteins (table 3 ) revealed an inhibition by $\mathrm{D}$-galactose and some derivatives. The most potent inhibitory substance was $\mathrm{N}$-acetyl-galactosamine at a concentration of $12.5 \mathrm{mM}$. From the glycoproteins tested, porcine stomach mucin was the only substance to show inhibitory activity. The hemagglutinating activity of the lectin was completely abolished by treatment with $5 \mathrm{mM}$ EDTA. Addition of $5 \mathrm{mM} \mathrm{CaCl}_{2}$ or $\mathrm{MnCl}_{2}$ resulted in total recovery of the hemagglutinating activity.

Table 2. Amino acid composition of the lectin from Vidalia obtusiloba.

\begin{tabular}{lrcc}
\hline Amino acid & Mol \% & Amino acid & Mol \% \\
\hline Asx & 10.17 & Ile & 5.25 \\
Thr & 5.06 & Leu & 7.85 \\
Ser & 5.17 & Tyr & 5.75 \\
Glx & 13.35 & Phe & 5.35 \\
Gly & 6.35 & His & 2.52 \\
Ala & 6.82 & Lys & 6.89 \\
Cys & 1.23 & Arg & 5.26 \\
Val & 5.69 & Pro & 3.33 \\
Met & 1.11 & Trp & 2.84 \\
\hline
\end{tabular}

The lectin was not affected by exposure to a temperature of $50{ }^{\circ} \mathrm{C}$ for $30 \mathrm{~min}$ but declined rapidly, reaching $12 \%$ of the control value, when heated at $70^{\circ} \mathrm{C}$ for $10 \mathrm{~min}$. The hemagglutinating activity was almost abolished when the lectin was heated at $90{ }^{\circ} \mathrm{C}$ for $20 \mathrm{~min}$ and totally abolished after $30 \mathrm{~min}$. The energy of activation of denaturation process (DG') was estimated to be $25.4 \mathrm{kcal}$. $\mathrm{Mol}^{-1}$ at $90{ }^{\circ} \mathrm{C}$.

\section{Discussion}

Guar gum is a galactomannan composed of a chain of $\beta(1 \rightarrow 4)$ linked D-mannopyranosyl residues having attached $\alpha$-D-galactopyranosyl unit linked $\alpha(1 \rightarrow 6)$ as single unit side chains, to approximately one half of the $\beta$-D-mannosyl residues (Lonngren et al. 1976, Appukuttan et al. 1977). The haemagglutinating activity in the fraction obtained by ion exchange chromatography (PII-DEAE) was bound completely to the cross-linked guar gum and eluted from this affinity column in pure form. Guar gum affinity chromatography has been used in the purification of galactose derivative-binding lectins
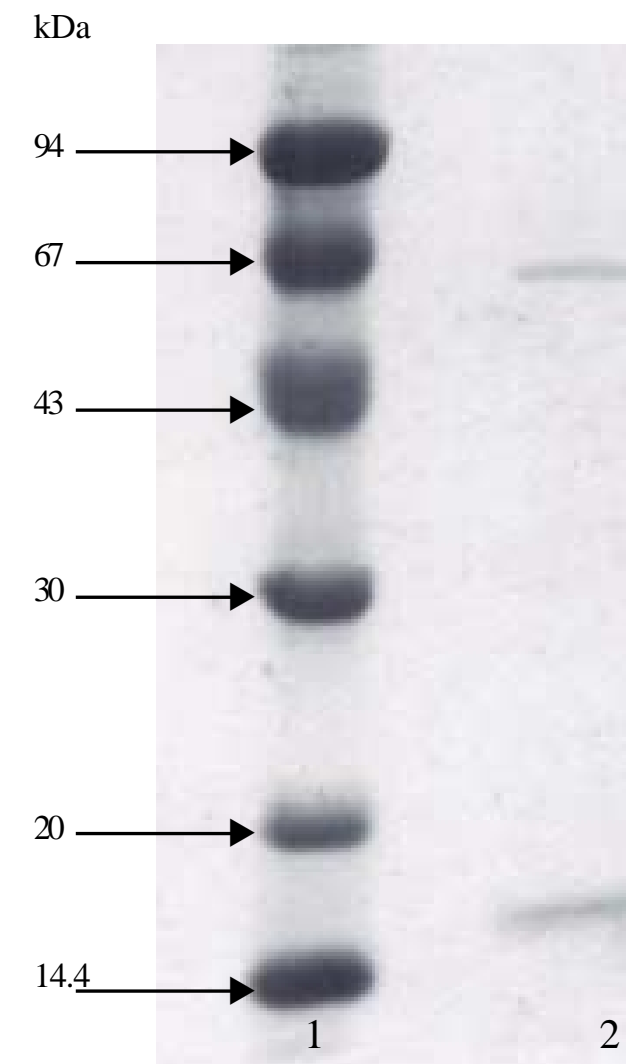

Figure 3. SDS-PAGE of lectin from Vidalia obtusiloba. Molecular weight markers, starting at the anode, were: phosphorylase $\mathrm{b}$, bovine serum albumin, ovalbumin, carbonic anhydrase, trypsin inhibitor and a-lactoferrin (Lane 1). Lane 2 corresponds to purified lectin. 
Table 3. Inhibition of the haemagglutinating activity of Vidalia obtusiloba lectin. NI = Substance was nonihibitory at a concentration of $100 \mathrm{mM}$ or $2.5 \mathrm{mg}$. $\mathrm{mL}^{-1}$.

\begin{tabular}{lc}
\hline Substance & Minimum inhibitory concentration \\
\hline L-arabinose & $\mathrm{NI}$ \\
N-acetyl-galactosamine & $3.12 \mathrm{mM}$ \\
D-celobiose & $\mathrm{NI}$ \\
D-fructose & $\mathrm{NI}$ \\
D-fucose & $\mathrm{NI}$ \\
L-fucose & $\mathrm{NI}$ \\
D-galactosamine & $12.50 \mathrm{mM}$ \\
D-galactose & $25.00 \mathrm{mM}$ \\
D-glucosamine & $\mathrm{NI}$ \\
D-glucose & $\mathrm{NI}$ \\
$\alpha$-lactose & $25.00 \mathrm{mM}$ \\
D-mannose & $\mathrm{NI}$ \\
D-raffinose & $\mathrm{NI}$ \\
L-rhamnose & $\mathrm{NI}$ \\
salicin & $\mathrm{NI}$ \\
D-xylose & $\mathrm{NI}$ \\
Avidin & $\mathrm{NI}$ \\
fetuin & $\mathrm{NI}$ \\
Porcine stomach mucin & $62.50 \mu \mathrm{g} . \mathrm{mL}^{-1}$ \\
yeast mannan & $\mathrm{NI}$ \\
\hline
\end{tabular}

(Sampaio et al. 1998). Many lectins from marine algae have been isolated by this technique, such Ptilota filicina J. Agardh (Sampaio et al. 1998), Enantiocladia duperreyi (C. Agardh) Falkenberg (Benevides et al. 1998) and Caulerpa cupressoides (Vahl) C. Agardh (Benevides et al. 2001).

Most of the lectins isolated from marine algae are low molecular weight proteins (Rogers \& Hori 1993), with the smallest value being reported for the lectins from the marine red algae Bryothamnion triquetrum (Gmelin) Howe and B. seaforthii (Turner) Kützing, with values of 3.5 and $4.5 \mathrm{kDa}$, respectively (Ainouz et al. 1995). Therefore, the native molecular mass $(78.9 \mathrm{kDa})$ estimated for Vidalia obtusiloba lectin by gel filtration on Sephadex G-100, was considered high when compared with lectins isolated from most species of marine algae. This value was larger than those reported for Ptilota serrata Kützing (64.5 kDa, Rogers et al. 1990), Caulerpa cupressoides (Vahl) C. Agardh (44.7 kDa, Benevides et al. 2001), Plumaria elegans (Bonnem.) Schmitz (35.5 kDa, Rogers et al. 1990), and Enantiocladia duperreyi (C. Agardh) Falkenberg (24.7 kDa, Benevides et al. 1998), but smaller than that for
Gracilaria tikvahiae McLachlan (150 kDa, Chiles $\&$ Bird 1990). When the lectin was submitted to SDSPAGE in the presence of $\beta$-mercaptoethanol, revealed the presence of two protein band (59.6 and $15.2 \mathrm{kDa})$, suggesting that the lectin from $V$. obtusiloba is probably a dimeric protein comprised of two kinds of subunits.

The lectin isolated from Vidalia obtusiloba was found to contain only one acidic isoelectric point, between 4 and 5. Although some lectins isolated from marine algae possess various isolectins, such as Codium tomentosus (Huds) Stackhouse (Fabregas et al. 1988) and Amansia multifida Lamouroux (Costa et al. 1999), most of the lectins isolated from red marine algae possess only one isolectin as observed for the lectins of Cystoclonium purpureum (Huds.) Batters (Kamiya et al. 1980), Gracilaria bursa-pastoris (Gmelin) Silva (Okamoto et al. 1990) and Gracilaria verrucosa (Hudson) Papenfus (Kanoh et al. 1992).

The amino acid composition of marine algal lectins includes predominantly acidic amino acids (glutamic and aspartic acid) and hydroxyl amino acids (serine and threonine) and low amounts of basic amino acids (lysine, histidine and arginine) (Okamoto et al. 1990, Hori et al. 1990, Benevides et al. 1996). The large proportion of acidic amino acids in Vidalia obtusiloba lectin reflects the composition of other marine algal lectins, which may account for the acidic pI observed in Vidalia obtusiloba lectin, as for some algal lectins such as Solieria filiformis (Kützing) Gabrielson (Benevides et al. 1996), Ulva lactuca L. (Sampaio et al. 1998) and Caulerpa cupressoides (Vahl) C. Agardh, (Benevides et al. 2001). Carbohydrate analysis by the phenol-sulphuric acid method suggest that the $V$. obtusiloba lectin is a glycoprotein, as are other agglutinins from marine algae, such as Gracilaria bursa-pastoris (Gmelin) Silva (Okamoto et al. 1990), Enantiocladia duperreyi (C. Agardh) Falkenberg (Benevides et al. 1998) and Caulerpa cupressoides (Vahl) C. Agardh (Benevides et al. 2001).

In contrast to the great majority of algal lectins (Rogers et al. 1990, Rogers \& Hori 1993), hemagglutinating activity exhibited by the purified lectin of Vidalia obtusiloba was inhibited by simple sugars, and the most potent inhibitory substance was N-acetylgalactosamine $(3.12 \mathrm{mM})$. The lectin was also inhibited by $\mathrm{D}$-galactose and others derivatives ( $\alpha$-lactose and D-galactosamine), and was strongly inhibited by the glycoprotein porcine stomach mucin $\left(62.5 \mu \mathrm{g} \cdot \mathrm{mL}^{-1}\right)$, a glycoprotein with a terminal GalNAc residue, and fucose and galactose as internal residues (Slomiany \& Mayer 1972). Similar observations of inhibition by mucin on 
red algal lectins were reported for Ptilota filicina J. Agardh (Sampaio et al. 1998), Enantiocladia duperreyi (C. Agardh) Falkenberg (Benevides et al. 1998), Ptilota serrata Kützing (Sampaio et al. 1999) and Pterocladiella capillacea Santel \& Hommers (Oliveira et al. 2002).

The hemagglutinating activity of Vidalia obtusiloba lectin was completely abolished when $5 \mathrm{mM}$ EDTA was added to the reaction medium. Since EDTA is a strong chelating reagent and total agglutination capacity was restored upon the addition of divalent cations $\left(\mathrm{Ca}^{++}\right.$and $\mathrm{Mn}^{++}$) to the reaction medium, it can be concluded that the lectin is dependent on these ions for its activity.

The hemagglutinating activity of Vidalia obtusiloba lectin declined rapidly when heated at 70 and $90{ }^{\circ} \mathrm{C}$ for $10 \mathrm{~min}$ and was totally abolished at $90^{\circ} \mathrm{C}$ after $30 \mathrm{~min}$, indicating that the activity of the lectin depends on its native conformation. The energy of activation of denaturation process $\left(\Delta \mathrm{G}^{\prime}\right)$ was estimated to be $25.4 \mathrm{Kcal} \mathrm{Mol}^{-1}$, which is similar to the values found for the lectin isolated from Pterocladiella capillacea Santel \& Hommers (Oliveira et al. 2002).

Acknowledgements - This work was supported by Coordenação de Aperfeiçoamento de Pessoal de Nível Superior (Capes), Conselho Nacional de Desenvolvimento Científico e Tecnológico (CNPq), Financiadora de Estudos e Projetos (Finep) and Fundação Cearense de Amparo à Pesquisa (Funcap).

\section{References}

AINOUZ, I.L., SAMPAIO, A.H., FREITAS, A.L.P., BENEVIDES, N.M.B. \& MAPURUNGA, S. 1995. Comparative study on haemagglutinins from the red algae Bryothamnion seaforthii and Bryothamnion triquetrum. Revista Brasileira de Fisiologia Vegetal 7:15-19.

APPUKUTTAN, P.S., SUROLIA, A. \& BACHHAWAT, B.K. 1977. Isolation of two galactose-binding proteins from Ricinus communis by affinity chromatography. Indian Journal of Biochemistry 14:382-384.

BENEVIDES, N.M.B., LEITE, A.M. \& FREITAS, A.L.P. 1996. Atividade hemaglutinante na alga vermelha Solieria filiformis. Revista Brasileira de Fisiologia Vegetal 8:117-122.

BENEVIDES, N.M.B., HOLANDA, M.L., MELO, F.R., FREITAS, A.L.P. \& SAMPAIO, A.H. 1998. Purification and partial characterisation of the lectin from the marine red alga Enantiocladia duperreyi (C. Agardh) Falkenberg. Botanica Marina 41:521-525.
BENEVIDES, N.M.B., HOLANDA, M.L., MELO, F.R., PEREIRA, M.G., MONTEIRO, A.C.O. \& FREITAS, A.L.P. 2001. Purification and partial characterization of the lectin from the marine green alga Caulerpa cupressoides (Vahl) C. Agardh. Botanica Marina 44:12-22.

BLUM, H., BEIER, H. \& GROSS, J.K. 1987. Improved silverstaining of plant proteins, RNA and DNA in polyacrylamide gels. Electrophoresis 8:93-99.

BRADFORD, M.M. 1976. A rapid and sensitive method for the quantitation of microgram quantities of protein utilizing the principle of protein-dye binding. Analytical Biochemistry 72:248-254.

CALVETE, J.J., COSTA, F.H.F., SAKER-SAMPAIO, S., MURCIANO, M.P.M., NAGANO, C.S., CAVADA, B.S., GRANGEIRO, T.B., RAMOS, M.V., BLOCH JR., C., SILVEIRA, S.B., FREITAS B.P. \& SAMPAIO, A.H. 2000. The amino acid sequence of the agglutinin isolated from the red marine alga Bryothamnion triquetrum defines a novel lectin structure. Cellular and Molecular Life Sciences 57:343-350.

CHILES, T.C. \& BIRD, K.T. 1990. Gracilaria tickvahiae agglutinin. Partial purification and preliminary characterization of its carbohydrate specificity. Carbohydrate Research 207:319-326.

COSTA, F.H.F., SAMPAIO, A.H., NEVES, S.A., ROCHA, M.L.A., BENEVIDES, N.M.B. \& FREITAS, A.L.P. 1999. Purification and characterization of a lectin from the red marine alga Amansia multifida. Physiology and Molecular Biology of Plants 5:53-61.

DAWES, E.A. 1972. Quantitative problems in biochemistry. The Williams \& Wilkins Co., Baltimore.

DUBOIS, M., GILLES, K.A., HAMILTON, J.K., REBERS, P.A. \& SMITH, F. 1956. Colorimetric method for determination of sugars and related substances. Analytical Chemistry 28:350-356.

FABREGAS, J., MUÑOZ, A., LLOVO, J. \& CARRACEDO, A. 1988. Purification and partial characterization of tomentine. An N-acetylglucosamine-specific lectin from the green alga Codium tomentosum (Huds) Stackh. Journal of Experimental Marine Biology and Ecology 124:21-30.

GABIUS, H.J. \& GABIUS, S. 1997. Glycoscience: status and perspectives, Chapman \& Hall, Weinheim.

GOODWING, T.W. \& MORTON, R.A. 1946. The spectrophotometric determination of tyrosine and tryptophan in proteins. Biochemical Journal 40:628-632.

HAMES, B.D. \& RICKWOOD, D. 1983. Gel electrophoresis of proteins. A pratical approach. IRL Press, Washington.

HORI, K., MIYAZAWA, K. \& ITO, K. 1990. Some common properties of lectins from marine algae. Hydrobiologia 204/205:561-566.

HORI, K., MATSUBARA, K. \& MIYAZAWA, K. 2000. Primary structures of two hemagglutinins from the marine red alga, Hypnea japonica. Biochimica et Biophysica Acta 1474:226-236. 
KAMIYA, H., SHIOMI, K. \& SHIMIZU, Y. 1980. Marine biopolymers with cell specificity-III-Agglutinins in the red alga Cystoclonium purpureum: isolation and characterization. Journal of Natural Products 43:136-139.

KANOH, H., KITAMURA, T. \& KOBAYASHI, Y. 1992. A sulfated proteoglycan from the red alga Gracilaria verrucosa is a hemagglutinin. Comparative Biochemistry and Physiology 102: 445-449.

LIS, H. \& SHARON, N. 1998. Lectins: carbohydrate specific proteins that mediate cellular recognition. Chemical Reviews 98:637-674.

LONNGREN, J., GOLDSTEIN, I.J. \& BYWATER, R. 1976. Cross-linked guar gam: a versatile immunosorbent for D-galactopyranosyl binding lectins. FEBS Letters 68:31-34.

MORAES, S.M.D., CAVADA, B.S., MOREIRA, R.A., ROQUEBARREIRA, M.C., SANTOS-DE-OLIVEIRA, R., PINTO, V.P.T. \& OLIVEIRA, J.T.A. 1996. Purification, physicochemical characterization and biological properties of a lectin from Erythrina velutina forma aurantiaca seeds. Brazilian Journal of Medical and Biological Research 29:977-985.

OKAMOTO, R., HORI, K., MIYAZAWA, K. \& ITO, K. 1990. Isolation and characterization of a new hemagglutinin from the red alga Gracilaria bursa-pastoris. Experientia 46:975-977.

OLIVEIRA, S.R.M., NASCIMENTO, A.E., LIMA, M.E.P., LEITE, Y.F.M.M. \& BENEVIDES, N.M.B. 2002. Purification and characterisation of a lectin from the red marine alga Pterocladiella capillacea Santel \& Hommers. Revista Brasileira de Botânica 25:397-403.
ROGERS, D.J. \& HORI, K. 1993. Marine algal lectins: new developments. Hydrobiologia 260/261:589-593.

ROGERS, D.J., FISH, B. \& BARWELL, C.J. 1990. Isolation and properties of lectins from two red marine algae: Plumaria elegans and Ptilota serrata. In Lectins: Biology, Biochemistry, Clinical Biochemistry. (T.C. BogHansen \& D.L.J. Freed, eds.). Sigma Chemical Company, St. Louis, v.7, p.49-52.

SAMPAIO, A.H., ROGERS, D.J. \& BARWELL, C.J. 1998. A galactose-specific lectin from the red marine alga Ptilota filicina. Phytochemistry 48:765-769.

SAMPAIO, A.H., ROGERS, D.J., BERWELL, C.J., SAKERSAMPAIO, S., COSTA, F.H.F. \& RAMOS, M.V. 1999. A new isolation procedure and further characterisation of the lectin from the red marine alga Ptilota serrata. Journal of Applied Phycology 10:539-546.

SHARON, N. \& LIS, H. 1989. Lectins. Chapman and Hall, London.

SHIOMI, K., YAMANAKA, H. \& KIKUCHI, T. 1981. Purification and physicochemical properties of a hemagglutinin (GVA- 1) in the red alga Gracilaria verrucosa. Bulletin of the Japanese Society of Scientific Fisheries 47:1079-1084.

SLOMIANY, D.L. \& MEYER, K. 1972. Isolation and structural studies of sulphated glycoproteins of hog gastric mucin. Journal of Biological Chemistry 247:5062-5070.

VAN DRIESSCHE, E., ROUGÉ, P., BEECKMANS, S. \& BOGHANSEN, T.C. (eds). 1996. Lectins - Biology, Biochemistry, Clinical Biochemistry, v.11, Textop, Denmark. 